\title{
Who Are We Afraid of? Indiana's Criminal REFORM AND HOW IT FAILS TO ADDRESS THOSE WITH Mental IllnesS AND SubSTANCE USE Disorder
}

\author{
BRE ROBINSON*
}

INTRODUCTION

"We are trying to separate the people we are mad at [from] the people we are afraid of, and deal with them differently.""

According to Indiana Representative Greg Steuerwald, the author of House Enrolled Act 1006 ("HEA 1006"), the quote above was the mission of Indiana's first criminal reform effort in over thirty years. ${ }^{2}$ The Act includes keeping nonviolent offenders out of the "scarce prison space" so dangerous offenders can be kept in prison longer. ${ }^{3}$ Consequently, low-level offenders with mental illness and substance use disorders are siphoned into county jails without effective rehabilitation treatment. ${ }^{4}$ As a result, county jails are overcrowded and Indiana's criminal reform is failing to address the root cause-lack of treatment for individuals with mental illness and substance use disorder. ${ }^{5}$

HEA 1006 was meant to reduce prison overcrowding, but it increased jail overcrowding. ${ }^{6}$ Jail commanders report that their jails are filled with more individuals that have drug-related charges than before the enactment of HEA $1006 .^{7}$ In an attempt to thwart jail overcrowding, the Indiana Supreme Court signed an order adopting Rule 26 of the Indiana Rules of Criminal Procedure ("Rule 26"), the state's effort to join several states across the nation that have adopted pretrial reform. ${ }^{8}$ The Rule requires Indiana courts to "utilize the results

* J.D. 2021, Indiana University Robert H. McKinney School of Law; B.A. 2013, Indiana University - Bloomington, Indiana. I would like to thank Professor Lahny Silva for her invaluable support in writing this Note, and her encouragement of me to challenge how to make our criminal justice system more just.

1. Indiana Counties, Jail Overcrowding Task Force, YouTube at 15:00 (Sept. 30, 2019), https://www.youtube.com/watch?v=18L055ylhcM\&feature=youtu.be [https://perma.cc/SQ4HHKDV] [hereinafter Sept. 30 Meeting].

2. Id.

3. Ind. Criminal Justice Inst. \& Justice Reinv. Advisory Council, Annual EVALUATION OF INDIANA's CRIMINAL CODE REFORM 23 (2018), http://184.175.130.101/legislative/ 2021/publications/agency/reports/icji/\#document-e94991c9 [https://perma.cc/6KYR-H77U] [hereinafter 2018 AnNuAl Evaluation].

4. Id. at 75 .

5. Jail Overcrowding TASK Force, 2019 Report 5 (2019), https:/www.in.gov/ judiciary/iocs/files/jail-overcrowding-report.pdf [https://perma.cc/9AJC-DVQS].

6. See 2018 Annual Evaluation, supra note 3.

7. Id. at 88 .

8. See Mitch Arvidson, Time to Bail on Cash Bail? A Growing Number of States are Scrutinizing Current Systems, and Exploring Alternatives Such as Use of Risk-Assessment Tools, 
of an evidence-based risk assessment" to determine "whether an arrestee presents a substantial risk of flight or danger to [them]self . . . or to the public." results of the assessment determine whether the court can release the individual on his or her own recognizance. ${ }^{10}$ Since offenders with mental illness and substance use disorder are often perceived as dangerous by police, prosecutors, and judges, the assessment may yield biased results against these individuals. ${ }^{11}$ Consequently, both the Indiana legislature and Indiana Supreme Court have failed to establish legitimate criminal reform.

This Note argues that Indiana's criminal reform fails to address individuals with mental illness and substance use disorder. As a result, county jails are overcrowded, and Indiana is not addressing the driving factor leading to these crimes. While Indiana has sought remedies to address the unintended effects of HEA 1006, both the Indiana legislature and Indiana Supreme Court have failed to establish adequate reform that encompasses individuals with mental illness and substance use disorder. Even Rule 26 may not reduce jail overcrowding because these individuals experience bias during pretrial screening and may reoffend when on pretrial release.

Part I of this Note examines the political, social, and economic drive behind HEA 1006. More specifically, this Part examines the purpose of the Act and the way it remains unfulfilled. In Part II, this Note discusses Rule 26 and its shortcomings in addressing individuals with mental illness and substance use disorder. Part III recommends reform that addresses mental illness and substance use disorder, which will in turn reduce jail overcrowding, reduce economic spending, and create sustainable criminal reform.

\section{HEA 1006: ITS INTENT, FAILURE, AND BURDEN ON JAILS}

\section{A. Background}

Prisons are expensive institutions. ${ }^{12}$ In 2015 , Indiana spent over $\$ 500$ million on prison expenditures, averaging roughly $\$ 18,065$ per inmate. ${ }^{13}$ Policymakers for reform tend to assume that a decline in prison population will result in a decline in spending. ${ }^{14}$ As a consequence of the 2008 recession, "lawmakers in

Council St. Gov'Ts (May 2, 2019, 5:24 PM), https://knowledgecenter.csg.org/kc/content/timebail-cash-bail-growing-number-states-are-scrutinizing-current-systems-and-exploring [https://perma.cc/9MJP-VWYC]; IND. R. CRIM. P. 26.

9. IND. R. CRIM. P. 26(B).

10. Id.

11. Am. Civil Liberties Union, Blueprint for Smart Justice: Indiana 17 (2019), https://50stateblueprint.aclu.org/assets/reports/SJ-Blueprint-IN.pdf [https://perma.cc/JR5B-3DZ3].

12. See Chris Mai \& Ram Subramanian, Vera Inst. of Justice, The Price of Prisons: Examining State SPEnding TRends, 2010-2015, at 7 (2017), https:/www.vera.org/downloads/ publications/the-price-of-prisons-2015-state-spending-trends.pdf [https://perma.cc/78TA-ZB9B].

13. Id. at 8,12 .

14. Id. at 10 . 
nearly every state," regardless of political affiliation, "enacted new laws to reduce prison populations," and in turn, spending. ${ }^{15}$ "While the national state imprisonment rate dropped 8 percent between 2000 and 2016, Indiana's imprisonment rate grew 18 percent." ${ }^{16}$ Indiana's surging incarceration rate was largely due to its failure to divert drug offenders from state prisons in the midst of the heroin epidemic. ${ }^{17}$ In 2013, Indiana passed HEA 1006 in response to its ever-increasing incarceration rate. ${ }^{18}$

HEA 1006 was lauded as a bipartisan effort to develop alternatives to incarceration while adding proportionality to Indiana's sentencing guidelines. ${ }^{19}$ The goals of HEA 1006 included: (a) "reduc[ing] crime by promoting the use of evidence based best practices"; (b) increasing sentences for violent crimes such as murder; and (c) decreasing the sentences for crimes $^{20}$ such as drug possession and resisting arrest. HEA 1006's evidence-based best practices, which are proven effective at reducing an offender's risk of recidivism, included providing $\$ 50$ million annually to community correction efforts, ${ }^{21}$ sending Level 6 offenders to county jails to be closer to their families, and keeping violent and non-violent offenders separate. ${ }^{22}$ Numerous studies show that incarcerated individuals with

\section{Id. at 4 .}

16. Am. Civil LiBerties Union, supra note 11, at 4 (citation omitted).

17. Josh Keller \& Adam Pearce, A Small Indiana County Sends More People to Prison Than San Francisco and Durham, N.C., Combined. Why?, N.Y. Times (Sept. 2, 2016), https://www. nytimes.com/2016/09/02/upshot/new-geography-of-prisons.html [https://perma.cc/69N3-NHXF].

18. Am. Civil LiBerties Union, supra note 11, at 4.

19. Alternative Sentencing Beneficial for Inmates, Beneficial for Hoosiers, IND. HousE Democratic CAucus (Feb. 23, 2015), https://indianahousedemocrats.org/news-media/alternativesentencing-beneficial-for-inmates-beneficial-for-hoosiers [https://perma.cc/53NV-3NTV].

20. 2018 Annual Evaluation, supra note 3, at 23.

21. See Alternative Sentencing Beneficial for Inmates, supra note 19.

22. See Deanna Allbrittin, While Local Jails Struggle with Overcrowding, State Closes Under-Capacity Prisons, CBS4 (June 14, 2017), https://cbs4indy.com/news/while-local-jailsstruggle-with-overcrowding-state-closes-under-capacity-prisons/ [https://perma.cc/J8ZA-QESU]; Kristine Guerra, House Passes $\$ 80$ Million Criminal Justice Bill, Indianapolis STAR (Feb. 23, 2015), https://www.indystar.com/story/news/crime/2015/02/23/house-passes-million-criminaljustice-bill/23895109/ [https://perma.cc/WL8N-7GCG]; Madeline Buckley \& Kristine Guerra, Can Indiana Trade Overcrowded Jails for Treatment Reform?, INDIANAPOLIS STAR (July 10, 2016), https://www.indystar.com/story/news/crime/2016/07/10/can-indiana-trade-overcrowded-jailstreatment-reform/85307540/ [https://perma.cc/QP3W-KQ3B]. The prisons and county jails are supplemented by community-based corrections, which include probation, parole, and pretrial supervision. The purpose of community corrections is to supervise individuals involved in the criminal justice system while keeping them out of jail. Correction supervision typically includes services such as mental illness and substance abuse treatment, employment assistance, and anger management. See Vera Inst. of Justice, The Potential of Community Corrections to IMPROVE SAFETY AND REDUCE INCARCERATION 2 (2013), https://www.vera.org/downloads/ Publications/the-potential-of-community-corrections-to-improve-safety-and-reduce-incarcerationconfigure/legacy_downloads/potential-of-community-corrections.pdf [https://perma.cc/G72W- 
supportive family members are less likely to recidivate. ${ }^{23}$ Additionally, keeping violent offenders from non-violent offenders provides opportunity to rehabilitate the non-violent offenders. ${ }^{24}$

HEA 1006 has curtailed growth in the prison population, but at the expense of an increasing jail population. ${ }^{25}$ Indiana's county jails detain arrestees, hold individuals who have not been sentenced, and house the least serious level of convicted felons, Level 6 offenders. ${ }^{26}$ The jail population has increased 368\% since the enactment of HEA 1006, and the prison population has only declined $27 \%{ }^{27}$ Further, the number of Level 6 filings has increased 32\% from 2015 to $2018 .^{28}$ What is most striking is that the top four felony filings in 2018 and 2019 were: (1) Possession of Meth, (2) Syringe Possession, (3) Theft with Prior, and (4) Narcotics Possession. ${ }^{29}$ Theft is frequently associated with substance use disorder because individuals with addiction may steal or rob to support their habit. ${ }^{30}$ These numbers demonstrate how the current strategies implemented by county jails and community corrections do not rise to the level of sophistication required to successfully support individuals with mental illness ${ }^{31}$ and substance

FCAA].

23. Margaret diZerega \& Sandra Villalobos Agudelo, Vera Inst. of Justice, Piloting a Tool for Reentry: A Promising Approach to Engaging Family Members 4 (2011), https://www.vera.org/downloads/Publications/piloting-a-tool-for-reentry-a-promisingapproach-to-engaging-family-members/legacy_downloads/Piloting-a-Tool-for-ReentryUpdated.pdf [https://perma.cc/5987-CS9A].

24. See generally Ind. Criminal Justice Inst. \& Justice Reinv. Advisory Council, Annual Evaluation of IndianA's CRiminal Code REFORm 70 (2019), https://www.in.gov/cji/ grant-opportunities/files/Final-Evaluation-of-Criminal-Code-Reform-HEA-1006.pdf [https://perma.cc/HC35-QLHM] [hereinafter 2019 ANNUAL EvALUATION].

25. See 2018 Annual Evaluation, supra note 3, at 88.

26. Associated Press, Many Indiana Counties Face Overcrowding Jails, ABC57 (Oct. 6, 2018, 4:53 PM), https://www.abc57.com/news/many-indiana-counties-face-overcrowding-jails [https://perma.cc/R9GZ-6NPE]. In Indiana, there are eighteen state prisons, all of which are operated under the Indiana Department of Correction (IDOC). Rob Carter, Commissioner's Welcome, InD. DeP'T CoRRECTION, https://www.in.gov/idoc/2709.htm (last visited Sept. 4, 2021) [https://perma.cc/PU9S-3MLT]. There are ninety-two county jails. 2019 ANNUAL EvALUATION, supra note 24 , at 61 .

27. 2019 ANNUAL Evaluation, supra note 24, at 11.

28. Id.

29. Id. at 29 tbl.6.

30. Drug Addiction (Substance Use Disorder), MaYo ClinIC, https://www.mayoclinic.org/ diseases-conditions/drug-addiction/symptoms-causes/syc-20365112 (last visited Sept. 4, 2021) [https://perma.cc/Z52A-DTFL].

31. Mental illness and substance use disorder share common risk factors such as genetic vulnerabilities, environmental influences, and how the circuits in the brain that control reward, decision making, impulse control, and emotions operate. Mental illness can also contribute to drug addiction if the individual with mental illness uses drugs as a form of self-medication. Similarly, "substance use [disorder] can lead to changes" in the brain that ignite "an underlying predisposition 
use disorders. ${ }^{32}$

The slight decrease in prison population has not resulted in savings. ${ }^{33}$ While the prison population decreases, Indiana's spending on criminal justice has not. ${ }^{34}$ Instead, counties are forced to consider building new facilities while operating with limited funds, ${ }^{35}$ and individuals with mental illness and substance use disorder continue to cycle through the system because of a lack of effective treatment, consuming large portions of the limited operating budget. ${ }^{36}$

\section{B. HEA 1006's Lack of Savings}

The Indiana House of Representatives favored the passage of HEA 1006 because overcrowded prisons are financially burdensome to taxpayers. ${ }^{37}$ It costs an average of fifty-five dollars per day to incarcerate an individual in the IDOC. ${ }^{38}$ Forty-five of the fifty-five dollars supports overhead costs such as paying for guards, heating and cooling, and the facility itself. ${ }^{39}$ Under HEA 1006, Level 6 offenders - who would have been sentenced to the IDOC prior to the passage of HEA 1006 - are placed in county jails, and the state pays a thirty-five dollar per diem to the jail to cover food and staffing. ${ }^{40}$ As a result, the IDOC saves approximately ten dollars per day for each Level 6 offender sent to a county jail. ${ }^{41}$

The IDOC savings actually shifted a substantial fiscal burden onto county

to develop [a] mental illness." Common Comorbidities with Substance Use Disorders, NAT'L INST. ON DRUG ABUSE (Apr. 2020), https://www.drugabuse.gov/publications/research-reports/commoncomorbidities-substance-use-disorders/why-there-comorbidity-between-substance-use-disordersmental-illnesses [https://perma.cc/B6Z4-BKAX].

32. See Sept. 30 Meeting, supra note 1, at 29:40.

33. 2018 Annual Evaluation, supra note 3, at 88; Oliver Hinds \& Jack Norton, Crisis at the Crossroads of America: Jail Expansion as Prison Reform in Indiana, VERA InST. OF JustiCE (Oct. 16, 2018), https://www.vera.org/in-our-backyards-stories/crisis-at-the-crossroads-of-america [https://perma.cc/V7VP-RZLG].

34. 2018 AnNuAl Evaluation, supra note 3, at 88.

35. See Elizabeth DePompei, It Will Take More than a \$23M Expansion to Solve Johnson County's Jail Problem, InDIANAPOLIS ST AR (Feb. 10, 2020, 6:00 AM), https://www.indystar.com/ story/news/local/johnson-county/2020/02/10/johnson-county-jail-taxes-expanding-but-challengesremain/4479347002/ [https://perma.cc/3NEZ-MWQQ].

36. 2018 Annual Evaluation, supra note 3, at 88.

37. No More Room: Indiana's Prison Overhaul is Contributing to Jail Overcrowding, Rising Costs, RePublic (Mar. 12, 2019, 8:53 PM), http://www.therepublic.com/2019/03/13/no_more_ room_indianas_prison_overhaul_is_contributing_to_jail_overcrowding_rising_costs [https://perma.cc/GBX8-KSWF].

38. Andrew Falk et al., Sagamore Inst., Second Annual Evaluation of Indiana's CRIMINAL CODEREForms 74 (2016), https://secure.in.gov/cji/files/2016-Report_on_1006-Final.pdf [https://perma.cc/UJ36-PVRK].

39. Id.

40. Id. at 74-75.

41. Id. at 74 . 
jails. Based on research of nine Indiana jails, the average cost to house a jail inmate is almost fifty-nine dollars per day. ${ }^{42}$ Consequently, county jails are forced to cut budgets for food, medical care, and the minimal programming they were able to provide for inmates, creating even harsher conditions inside the facility. ${ }^{43}$ County jails were not intended to be "small prisons," but housing Level 6 offenders requires the jails to increase supervision costs. ${ }^{44}$ Ultimately, under HEA 1006 , the costs for incarceration have not decreased, but shifted from the prisons to the county jails, forcing county taxpayers to bear the costs of incarceration. ${ }^{45}$

In response to the increased cost to house Level 6 offenders, Clinton County implemented a pay-to-stay policy in $2019 .{ }^{46}$ The policy requires inmates found guilty of a felony or misdemeanor to pay thirty dollars for each day they are housed in the jail. ${ }^{47}$ Pay-to-stay policies have been deemed ineffective by other states. ${ }^{48}$ Pay-to-stay programs often do not produce savings. ${ }^{49}$ Jails spend almost as much as they save by trying to collect the fees, and recently released individuals will likely return to jail because of the debt they cannot pay. ${ }^{50}$ This ultimately continues the cycle of incarceration.

Indiana closed the Henryville IDOC facility in Clark County in July $2016 .{ }^{51}$ Closing the facility saved the state an estimated $\$ 2.25$ million in $2017 . .^{52}$ Representatives estimated that when enough inmates convicted of Level 6 felonies no longer needed the IDOC to house them, additional IDOC facilities would be able to close. ${ }^{53}$ But no other IDOC facilities have closed as of early 2020. In fact, Indiana enacted legislation that will cost $\$ 7.5$ million to remedy issues created by HEA $1006 .{ }^{54}$

42. 2019 AnNuAl Evaluation, supra note 24, at 85 .

43. Hinds \& Norton, supra note 33.

44. 2019 ANNUAL Evaluation, supra note 24, at 87, 93.

45. Hinds \& Norton, supra note 33.

46. Kelly Reinke, Indiana Inmates Found Guilty Will be Charged \$30 Per Day in Jail, LOCAL 12 (June 23, 2019), https://local12.com/news/nation-world/indiana-inmates-found-guiltywill-be-charged-30-per-day-in-jail [https://perma.cc/P89F-BEAF].

47. Id.

48. See Clinton County Pay-to-Stay Jail Ordinance: Bad Policy, ACLU Ind. (June 21, 2019, 4:15 PM), https://www.aclu-in.org/en/news/clinton-county-pay-stay-jail-ordinance-bad-policy [https://perma.cc/F5MT-AAC2] (“A pay-to-stay program in Ohio for example, was found to be 'a complete failure."').

49. Id.

50. Id.

51. FALK ET AL., supra note 38, at 75; Madeline Buckley, Closing Indiana Prison to Save \$2.25M, Officials Say, Courier J. (June 1, 2016, 4:08 PM), https://www.courier-journal.com/story/ news/local/indiana/2016/06/01/henryville-correctional-facility-close/85256156/ [https://perma.cc/9UJU-C3HN].

52. FALK ET AL., supra note 38, at 75.

53. Id.

54. Abigail Campbell \& Sydney Livingston, House Passes Frye's Bill Addressing Jail Overcrowding, Ind. House of Representatives Republican Caucus (Feb. 12, 2019), 


\section{The County Jail Overcrowding Problem}

Jail overcrowding is more than just an inconvenience, it is a constitutional violation. ${ }^{55}$ In 2016, inmates at Vigo County Jail successfully brought a class action against the Vigo County Sheriff, Greg Ewing, for violating their constitutional rights under the Eighth and Fourteenth Amendments because of the conditions of the jail. ${ }^{56}$ In Chief Judge Jane Magnus-Stinson's Order for Partial Summary Judgment, she noted that HEA 1006 and the opioid crisis were contributing factors to Indiana's increase in jail population. ${ }^{57}$ Due to the constant overcrowding, some inmates in Vigo County Jail had to sleep on mattresses on the floor. ${ }^{58}$ The Vigo County Sheriff conceded that the jail did not meet constitutional standards because of overcrowding, understaffing, and inadequate space. ${ }^{59}$ In fact, both parties and the court agreed that building a new jail was the only way to alleviate the violation of the inmates' constitutional rights. ${ }^{60}$

Jail overcrowding is not unique to Vigo County. The American Civil Liberties Union (ACLU) has filed more than a dozen suits in Indiana related to jail overcrowding. ${ }^{61}$ Its most recent suit, as of February 2020, against Wabash County Jail alleges that because of overcrowding, some inmates are housed in the indoor recreation room. ${ }^{62}$ The recreation room does not have a toilet or running water, and inmates have been given cups to urinate in and have to dump the urine down a drain in the floor of the recreation room. ${ }^{63}$ With Indiana's current criminal reform failing to reduce the inmate population, the only feasible solution is to build a new jail. The ACLU's attorney on the case, Stevie Pactor, says, "There is no way to renovate an existing structure to accommodate the number, the flow of inmates that the facility will be expected to house based on who is prosecuted

https://www.indianahouserepublicans.com/news/press-releases/house-passes-frye-s-bill-addressingjail-overcrowding/ [https://perma.cc/3N6R-R9J6]; Abrahm Hurt, Frye's Bill Focused on Alleviating Jail Overcrowding Signed into Law, Ind. House of RePresentATIVES RePublicAN CAuCus (Apr. 15, 2021), https://www.indianahouserepublicans.com/news/press-releases/frye-s-bill-focused-onalleviating-jail-overcrowding-signed-into-law/ [https://perma.cc/R5WM-C4ZJ].

55. See Huerta v. Ewing, No. 2:16-cv-00397-JMS-MJD, 2018 WL 4922038, at *6 (S.D. Ind. Oct. 10, 2018).

56. Id.

57. Id. at $* 3$.

58. Id.

59. $I d$. at $* 6$.

60. $I d$. at $* 8$.

61. Olivia Covington, ACLU Files Wabash County Jail Overcrowding Suit, IND. LAw. (Feb. 21, 2020), https://www.theindianalawyer.com/articles/aclu-files-wabash-county-jail-overcrowdingsuit [https://perma.cc/9PPB-6JRZ].

62. Class Action Complaint for Declaratory and Injunctive Relief at 5, Copeland v. Wabash Cty., No. 3:20-cv-00154 (N.D. Ind. Feb. 19, 2020) (No. 1).

63. Id. 
in that county." ${ }^{94}$ Accordingly, Indiana counties will continue to face legal ramifications until the inmate population is reduced, or counties build new jails.

The National Institute of Corrections defines overcrowding as a jail that is at $80 \%$ capacity. ${ }^{65}$ At $80 \%$ capacity, managing a diverse jail population becomes difficult and can lead to "increases in violence, increase[s] in the availability of contraband, and a break down in security." ${ }^{" 6}$ According to the Indiana jail inspector, a jail should never exceed $80 \%$ of its available bed capacity ${ }^{67}$; however, "[i]n $2019,66 \%$ of jails exceeded $80 \%$ capacity, . . . [and] $37 \%$ are over $100 \%$ capacity. ${ }^{68}$ Jail overcrowding exacerbates problems for individuals with mental illness ${ }^{69}$ Inmates who need to be kept separate from other inmates because of their mental illness, are unable to due to lack of space. ${ }^{70}$ It is not uncommon for a padded cell built for one inmate to hold three inmates on suicide watch. ${ }^{71}$

Four Indiana counties are building new jails in response to overcrowding, with an additional thirty-two counties considering proposals to construct new jails. $^{72}$ Building new facilities is expensive, but when a jail is overcrowded, the jail commander must find available space in other jails to house their inmates. ${ }^{73}$ Housing an inmate in another jail requires the overcrowded jail to pay a per diem to the other jail. ${ }^{74}$ Vigo County spends a staggering $\$ 1$ million a year to house inmates in other counties because of their overcrowding. ${ }^{75}$ Counties are not considering just building new facilities; some jail plans also include services uncommon in most jails. For example, Marion County is constructing a \$572 million criminal justice center which will include treatment for people suffering from mental illness and drug addiction. ${ }^{76}$

64. Darian Benson, ACLU Files Lawsuit Against Wabash County Jail, WFYI(Feb. 20, 2020), https://www.wfyi.org/news/articles/aclu-files-lawsuit-against-wabash-county-jail [https://perma.cc/G8GD-86Q9].

65. 2019 Annual Evaluation, supra note 24, at 12 (citing Mark D. Martin \& Paul Katsampes, Nat'L Inst. of CorR., U.S. Dep't of Justice, NiC Accession No. 021925, SherifF's Guide to EFFECTIVE JaIL Operations (2007)).

66. Id. at 61 .

67. Id.

68. Id. at 12 .

69. Barbara Brosher, Jail Overcrowding Exacerbates Problems for Those with Mental Illnesses, WFYI (Feb. 19, 2019), https://www.wfyi.org/news/articles/jail-overcrowdingexacerbates-problems-for-those-with-mental-illnesses-19sw [https://perma.cc/NPY2-Z94S].

70. Id.

71. Id.

72. No More Room, supra note 37.

73. Huerta v. Ewing, No. 2:16-cv-00397-JMS-MJD, 2018 WL 4922038, at*5 (S.D. Ind. Oct. 10, 2018).

74. Id.

75. Id.

76. James Briggs, Indianapolis Council Approves New Jail, Giving Mayor Joe Hogsett a Signature Achievement, INDIANAPOLIS STAR (Nov. 20, 2018), https://www.indystar.com/story/ news/local/marion-county/2018/11/19/mayor-joe-hogsetts-jail-plan-passes-through-city-county- 
Ironically, studies have shown increasing capacity does not have an impact on overcrowding. ${ }^{77}$ Increased capacity results in fewer offenders being diverted from jail. ${ }^{78}$ For example, Johnson County has a plan to add a \$23 million expansion to its facility but has acknowledged that by the time the taxpayers have paid for the expansion, ${ }^{79}$ the jail may need another. ${ }^{80}$ When jails are overcrowded, leadership is forced to make decisions about the people they will arrest. For example, Marion County found that minor marijuana possession charges were clogging courts and overcrowding jails, so the Prosecutor's Office decided they would no longer prosecute individuals for minor possession. ${ }^{81}$ These diversion efforts actually minimize the number of incarcerated individuals with mental illness and substance use disorder. ${ }^{82}$ This is why reform is the preferable alternative to resizing.

\section{The Legislature's Response to Overcrowding}

Representative Randall Frye introduced House Bill 1065 ("HB 1065"), enacted May 5, 2019, in response to jail overcrowding. ${ }^{83}$ The bill established the Jail Overcrowding Task Force and recommended "regional holding facilities," which are existing facilities that offer treatment for substance abuse and mental health, educational and vocational programs, and "other evidence based programs designed to reduce recidivism." 85 Further, a "regional holding facility lease agreement" may be established "for the purpose of: (1) addressing the issue of jail overcrowding in Indiana; (2) reducing recidivism by offering programs in the facility[;] . . . and (3) obtaining federal funding to operate the facility." ${ }^{" 86}$ County jails are under no obligation to transfer Level 6 offenders to the regional holding facilities, and may only do so when the jail is at $100 \%$ capacity. ${ }^{87}$

Representative Frye is unclear where the $\$ 7.5$ million for the pilot to fund HB

council/2056245002/ [https://perma.cc/ H22Y-K6FF].

77. See Joshua Guetzkow \& Eric Schoon, If You Build It, They Will Fill It: The Consequences of Prison Overcrowding Litigation, 49 LAW \& Soc'Y REV. 401, 426, (2015).

78. Id.

79. Taxpayers will pay a $0.2 \%$ increase in local income tax for over twenty years for the expansion. A family making $\$ 70,000$ a year will pay anywhere from $\$ 1,050$ to $\$ 2,800$ to fund the expansion over the life of the tax hike. DePompei, supra note 35.

80. Id.

81. Rich Van Wyk \& Steve Jefferson, Marion County Will No Longer Prosecute Simple Marijuana Cases, WTHR (Oct. 2, 2019), https://www.wthr.com/article/marion-county-will-nolonger-prosecute-simple-marijuana-cases [https://perma.cc/NP4W-LM29].

82. See id.

83. Campbell \& Livingston, supra note 54.

84. H.B. 1065, 121 st Gen. Assemb., 1st Reg. Sess. (Ind. 2019) (enacted).

85. IND. Code ANN. § 11-12-6.5-1(d) (West 2020).

86. Id.

87. Campbell \& Livingston, supra note 54. 
1065 will come from.$^{88}$ The holding facilities will be either newly constructed or renovated pre-existing buildings. ${ }^{89}$ Notably, Representative Frye suggested "the state could reopen Henryville Correctional Facility and use an unoccupied wing of [the] Madison Correctional Facility to accommodate the changes outlined in the proposal. ${ }^{.90}$ Closing facilities such as the Henryville Correctional Facility to save money was one of the goals of HEA 1006. ${ }^{91}$ Reopening Henryville to provide space for Level 6 offenders - who cannot serve their time in the county jail because of overcrowding - negates any fiscal success from HEA 1006. Further, under the bill, the transfer of Level 6 offenders is voluntary and may only be done when a jail is at $100 \%$ capacity. ${ }^{92}$ As noted earlier, the Indiana jail inspector has stated $80 \%$ is the recommended capacity and anything above $80 \%$ is dangerous to inmates and staff. ${ }^{93}$

Regional holding facilities also defeat the purpose of one of the evidencebased practices implemented in HEA 1006 - keeping low level offenders closer to their families. Regional holding facilities will not exist in every county, so many Level 6 offenders will be sent to facilities further away from home, making it harder for those offenders to maintain a relationship with family members. ${ }^{94} \mathrm{HB}$ 1065 will impede any savings from closing the Henryville Correctional Facility, ignore the harsh conditions in jails from overcrowding, and frustrate one of the purposes of Level 6 offenders going to county jails.

The Jail Overcrowding Task Force introduced by HB 1065 was comprised of Indiana Supreme Court Justices, Indiana Representatives, the IDOC Commissioner, and Indiana Sheriffs, who assessed jail overcrowding in Indiana for 148 days. ${ }^{95}$ The Task Force held regional meetings with presentations from the Division of Mental Health and Addiction, law enforcement officials, the Indiana Prosecuting Attorneys Council, the Indiana Public Defender Council, and the Probation Officers Professional Association of Indiana. ${ }^{96}$ In addition to regional meetings, the Task Force solicited the public for written comments on their website. ${ }^{97}$ After gathering information, the Task Force found that county jails are impacted by a high percentage of inmates with mental health and addiction issues, the lack of available treatment facilities and mental health beds at the state and local level, the bond amounts for individuals of limited means, the

88. Barbara Brosher, Bill Proposing Regional Holding Facilities Could Cost State \$7.5 Million, WBAA (Mar. 20, 2019), https://www.wbaa.org/post/bill-proposing-regional-holdingfacilities-could-cost-state-75-million\#stream/0 [https://perma.cc/4XE7-2V28] [hereinafter Brosher, Bill Proposing].

89. Campbell \& Livingston, supra note 54.

90. Brosher, Bill Proposing, supra note 88.

91. FALK ET AL., supra note 38, at 75.

92. Campbell \& Livingston, supra note 54.

93. 2019 Annual Evaluation, supra note 24, at 61; see supra Section I.C.

94. Brosher, Bill Proposing, supra note 88. Id.

95. JAIL Overcrowding TASK ForCe, supra note 5, at 1-2.

96. Id. at $3-4$.

97. Id. at 1 . 
number of pretrial detainees, and an increase in the number of Level 6 filings. ${ }^{98}$ None of the listed factors are resolved through quick fixes such as new jails or regional holding facilities. ${ }^{99}$

\section{E. HEA 1006's Forensic Treatment Services}

HEA 1006 established a new program called Recovery Works, managed under the Family and Social Service Administration's Department of Mental Health. ${ }^{100}$ The program is classified as a forensic treatment service that provides specially-skilled evaluations and treatment services to individuals with mental illness and substance use disorder. ${ }^{101}$ The services are aimed at promoting recovery and preventing criminal justice involvement. ${ }^{102}$ Recovery Works reimburses providers in Indiana that offer specialized services to individuals with mental illness and substance use disorder through their voucher-based program. ${ }^{103}$ The service providers funded by Recovery Works primarily offer participants individual skills training, group substance use disorder treatment, individual mental health treatment, and group skills training development. ${ }^{104}$ The skills training development is a re-entry service designed to help offenders as they transition back into society. ${ }^{105}$ HEA 1006 granted Recovery Works \$20 million for 2017, 2018, and 2019. ${ }^{106}$ Since its inception, the program has allocated $\$ 63,058,615$ for services, ${ }^{107}$ resulting in a $\$ 3,058,615$ deficit. At the end of the 2019 fiscal year, there were 13,492 participants enrolled in Recovery Works, ${ }^{108}$ compared to the 16,189 enrolled in $2018 .{ }^{109}$ The participant reduction is likely correlated to a lack of funding rather than a lack of individuals in need of services. ${ }^{110}$

Many counties found the program beneficial in the beginning but have since identified challenges within. ${ }^{111}$ Most counties need more inpatient and outpatient services to handle the number of individuals in need of services. ${ }^{112}$ These counties

98. Id. at 5 .

99. See id. at 1 .

100. About Recovery Works, FAM. \& SOC. SERvs. ADMIN., https://www.in.gov/fssa/dmha/ 2940.htm (last visited Sept. 5, 2021) [https://perma.cc/383H-SRW9].

101. Id.

102. $I d$.

103. Id.

104. 2019 ANNUAL Evaluation, supra note 24, at 67.

105. Id. at 105 .

106. Id. at 67; Policies and Procedures Manual, Recovery Works at 8 (Oct. 2019), https://www.in.gov/fssa/dmha/files/PP-Manual-Oct-2019-final.pdf [https://perma.cc/ME6S-UFZQ].

107. 2019 AnNual Evaluation, supra note 24, at 13.

108. Id.

109. Id. at 67.

110. Id. at 82 .

111. Id. at 83 .

112. Id. at 14 . 
have a waitlist anywhere from ninety days to nine months. ${ }^{113}$ This long wait can be detrimental to an individual struggling with mental health issues or substance abuse. ${ }^{114}$ Moreover, the program does not have the funding it did in the past which has resulted in some counties no longer accepting the Recovery Works vouchers because they are no longer reimbursed the full amount for their services. ${ }^{115}$ As a result, the counties operate at a loss when accepting the Recovery Works vouchers and cannot afford to lose money. ${ }^{116}$ With fewer counties accepting Recovery Works vouchers, there are fewer opportunities available for individuals in need to utilize the program.

An individual's access to Recovery Works is also limited by the eligibility requirements. Only individuals without Medicaid or private insurance who make less than $200 \%$ of the federal poverty line ${ }^{117}$ qualify. ${ }^{118}$ Additionally, an individual must have a current or prior felony conviction. ${ }^{119}$ There is also a lifetime cap on the amount an individual may receive through Recovery Works. ${ }^{120}$ After the cap is met, an individual must pay twenty dollars for each treatment session. ${ }^{121}$ If an individual has a Level 6 (or higher) charge that is ultimately reduced, the offender will no longer qualify for Recovery Works unless he or she has a prior criminal history. ${ }^{122}$ Since early intervention can drastically improve an individual's chance of success for recovery, this qualification is counterintuitive. ${ }^{123}$ Also, the lifetime cap can pose challenges for individuals who suffer from mental illness and substance use disorder. Homelessness and poverty are often associated with mental illness and substance use disorder, ${ }^{124}$ so a twenty-dollar self-pay blocks

113. 2018 AnNual Evaluation, supra note 3, at 16.

114. See Cristina Redko et al., Waiting Time as a Barrier to Treatment Entry: Perceptions of Substance Users, 36 J. DRUg Issues 831 (2006) ("Longer waits for treatment increase the opportunities that other events will arise, thereby further interfering with treatment entry.").

115. 2019 ANNUAL Evaluation, supra note 24, at 83.

116. Id.

117. For a household of one, $200 \%$ of the federal poverty line is $\$ 25,520$ and for a household of three, it is $\$ 43,440$. Office of the Assistant Sec'y for Planning \& Evaluation, Poverty Guidelines, U.S. DEP'T HEALTh \& Hum SERVs. (Jan. 8, 2020), https://aspe.hhs.gov/poverty-guidelines [https://perma.cc/5ERS-ELAW].

118. 2019 ANNUAL Evaluation, supra note 24, at 20.

119. Id.

120. The lifetime cap for Community Services, which include case management, mental health counseling, psychiatric assessments, and substance use disorder counseling, is $\$ 2,500$. The lifetime cap for Re-Entry Services, which include intensive outpatient treatment, mental health counseling, substance use disorder counseling, and skills and development training, is $\$ 1,500$. The lifetime cap for Recovery Residences’ services is $\$ 4,000$. Rate Sheet Appendix, RECOVERY WORKS at 2, 5-6, https://www.in.gov/fssa/dmha/files/RW-Rate-Sheet-Appendix.pdf (last visited Feb. 10, 2021) [https://perma.cc/5MDC-P78H].

121. 2019 AnNual Evaluation, supra note 24, at 83.

122. Id.

123. Id.

124. See Lillian Gelberg \& Barbara D. Leake, Substance Use Among Impoverished Medical 
access to treatment for many of these individuals. ${ }^{125}$ The individuals who meet the lifetime cap are generally classified as "high risk, high needs, repeat offenders who really need the high level of services." ${ }^{26}$ Since the individuals who are in dire need of mental health and substance use treatment are most likely to: (1) meet the lifetime cap; and (2) struggle to self-pay, the qualifications set out by Recovery Works fail to accommodate the most vulnerable individuals. Consequently, these individuals are more likely to return to jail.

\section{RULE 26: THE SUPREME COURT'S SOLUTION}

\section{A. The Adoption of Criminal Rule 26}

The Indiana Supreme Court adopted Criminal Rule 26-Indiana's first pretrial reform - on September 7, 2016, in response to county jail overcrowding. ${ }^{127}$ The Indiana Supreme Court established a partnership with the National Institute of Corrections in 2016 to study Evidence-Based Decision Making, which provided Indiana policymakers information regarding pretrial risk assessments. ${ }^{128}$ The study led to the adoption of Rule $26 .{ }^{129}$ The rule was codified as Indiana Code section 35-33-8 and went into effect for all Indiana courts on January $1,2020 .{ }^{130}$ Eleven counties participated in a pilot study of Rule 26 before it went into effect for all Indiana courts. ${ }^{131}$ Despite the Indiana Supreme Court's research, the Indiana Prosecuting Attorneys Council spoke out against the rule and asked the Supreme Court to rescind it. ${ }^{132}$ The Indiana Prosecuting Attorneys Council saw "no credible data or research that suggests a systemic pretrial detention 'problem' exists in Indiana." 133 Deputy Prosecuting Attorney Ryan Mears said the rule probably would not have a positive impact on jail overcrowding issues and might even exacerbate the issue. ${ }^{134}$ Further, he asserted

Patients: The Effect of Housing Status and Other Factors, 31 Med. CARE 757 (1993).

125. 2019 AnNual Evaluation, supra note 24, at 83.

126. $I d$.

127. Patrick Roth, Indiana Supreme Court Institutes New Rules on Bail, WSBT (Sept. 7, 2016), https://wsbt.com/news/local/indiana-supreme-court-institutes-new-rules-on-bail [https:// perma.cc/5RV4-AXNM]; see Jordan Fischer, Indiana Prosecutors Come Out Against 'Rule 26' Bail Changes for Low-Risk Arrestees, WRTV (Oct. 25, 2016), https://www.wrtv.com/news/ crime/indiana-prosecutors-come-out-against-rule-26-bail-reform-for-low-risk-arrestees [https://perma.cc/T6QQ-8TDU].

128. About, IND. OfF. CT. SERVs., https://www.in.gov/judiciary/iocs/3900.htm (last visited Sept. 4, 2021) [https://perma.cc/KW8U-HLH3].

129. Id.

130. Ind. Code ANN. § 35-33-8-0.5 to -12 (West 2020).

131. About, supra note 128.

132. Indiana Prosecutors' Request Withdrawal of Criminal Rule 26, Indiana Prosecuting Attorneys Council (Oct. 24, 2016) (on file with author).

133. Id.

134. Fischer, supra note 127. 
that pretrial reform would "drastically slow down the procedure of people requesting bail." 135

\section{B. The End of Monetary Bail?}

According to the Indiana Public Defender Council, the "purpose of monetary bail and other conditions of release from pretrial detention are to maximize the likelihood of an accused person's presence at trial while striving for both public safety and protection of the presumption of innocence." ${ }^{\prime 16}$ Releasing individuals who do not pose a risk to public safety can reduce recidivism and eliminate unnecessary expenses from overutilizing jail resources. ${ }^{137}$ The mission of Indiana's pretrial release reform is to:

(a) encourage and empower trial judges to release arrestees earlier; (b) reduce pretrial detention expenses for local jails and enable many arrestees to return to their jobs and provide support for their families; (c) eliminate the unfair . . . incarceration of poor people who [cannot] purchase a bail bond or pay a bail deposit; . . . and (e) realize the benefits of reduced recidivism and enhanced public safety ... . [by using] evidence-based risk assessment tools. ${ }^{138}$

Rule 26 eliminates monetary bail for arrestees who do not "present a substantial risk of flight or danger to the arrestee or others." ${ }^{\prime 39}$ Rule 26 certainly has benefits considering pretrial detainees are more likely to be found guilty of their crime compared to individuals released before trial (despite the presumption of innocence while on pretrial detainment). ${ }^{140}$ Also, $56 \%$ of the county jail population is composed of pretrial detainees. ${ }^{141}$ Many of these individuals are held in jail before trial because they cannot afford bail. ${ }^{142}$ Nevertheless, there are risks to Rule 26, especially when considering individuals with mental illness and substance use disorder. Some families leave the individual with mental illness or substance use disorder in jail because of an inaccurate perception that county jails

135. Id.

136. Pre-Trial Release Project, Ind. Pub. DefEnder Council, https://www.in.gov/ipde/ public/2745.htm (last visited Sept. 4, 2021) [https://perma.cc/MFG4-5KC5].

137. Id.

138. Id.

139. Ind. CODE ANN. § 35-33-8-3.8 (West 2020).

140. Will Dobbie et al., The Effects of Pretrial Detention on Conviction, Future Crime, and Employment: Evidence from Randomly Assigned Judges, 108 Am. ECON. REv. 201, 202-03 (2018) (“[P]retrial release decreases the probability of being found guilty by 14.0 percentage points.").

141. See, e.g., Ind. Criminal Justice Inst., Annual Evaluation of Indiana's Criminal CODE REFORM 13 (2017), https:/www.in.gov/cji/grant-opportunities/files/Research_1006_ Criminal_Evaluation_2017.pdf [https://perma.cc/55LF-74H9].

142. Patrick Liu et al., The Economics of Bail and Pretrial Detention, Hamilton Project at 3 (Dec. 2018), https://www.hamiltonproject.org/assets/files/BailFineReform_EA_121818_6PM.pdf [https://perma.cc/K7PL-Y5RM]. 
are rehabilitation facilities. ${ }^{143}$ The families mistakenly believe that jails can provide the necessary support to help the individual with his or her illness and that the individual is safer in jail than on the street. ${ }^{144}$ Risk assessment tools also have not been shown to eliminate bias in pretrial decision-making, which often impacts individuals with mental illness and substance use disorder. ${ }^{145}$

The court determines whether an individual poses a risk of flight or safety by using an evidence-based risk assessment tool which "identifies factors relevant to determine whether an arrestee is likely to: (i) commit a new criminal offense; or (ii) fail to appear." ${ }^{\text {"146 }}$ Indiana's evidence-based risk assessment was modeled after the Ohio Risk Assessment System (ORAS) and the Ohio Youth Assessment System (OYAS) and created specifically for Rule 26. ${ }^{147}$ The Indiana Risk Assessment System Pretrial Assessment Tool (IRAS-PAT) determines an offender's risk of Failure to Appear (FTA) to court on the offender's trial date and risk to reoffend during the pretrial period by looking at a series of factors, including: current offense charge, prior convictions, prior incarcerations, pending offense charge(s), history of FTA, community ties, residential stability, substance abuse, employment, education, and age. ${ }^{148}$ The assessment targets dynamic risk factors, which are "changeable features of individuals and their environments which predict higher rates of reoffending." ${ }^{149}$ Dynamic risk factors are the most effective at reducing recidivism. ${ }^{150}$ The assessment "was designed to be short" but to also include enough questions to gather a realistic assessment of whether the individual should be granted pre-trail release. ${ }^{151}$

An evaluation of the pilot program raises questions about whether the IRASPAT assessment results are presented to the court, whether the results are taken into consideration when pretrial decisions are made, and whether the court is reluctant to end monetary bail. ${ }^{152}$ The study analyzed data from cases where a

143. See Indiana Counties, Jail Overcrowding Task Force, YouTube at 2:13:02 (Nov. 6, 2019), https://www.youtube.com/watch?v=u9tRx3RFMyM [https://perma.cc/WA93-MPBD] [hereinafter Nov. 6 Meeting].

144. Id.

145. Am. Civil Liberties Union, supra note 11, at 5, 17.

146. Ind. CODE ANN. § 35-33-8-0.5 (West 2020).

147. The Indiana Risk Assessment System (IRAS) and the Indiana Youth Assessment System (IYAS), IND. JUD. BRANCH, https://www.in.gov/judiciary/iocs/2762.htm (last visited Sept. 4, 2021) [https://perma.cc/2ATY-KXJ5].

148. Eric Grommon et al., Process Evaluation of the IRAS-PAT Pilot Program IMPLEMENTATION 3 (2017), https://www.in.gov/judiciary/iocs/files/pretrial-pilot-eval-report-2017. pdf [https://perma.cc/3MQL-A988].

149. Roxanne Heffernan et al., Dynamic Risk Factors and Constructing Explanations of Offending: The Risk-Causality Method, 44 Aggression \& Violent Behav. 47, 48 (2019).

150. Edward Latessa et al., Ctr. For Criminal Justice Research, Validation of the InDiAnA Risk ASSESSMENT System: FinAL REPORT 7 (2013), https://www.in.gov/judiciary/ iocs/files/prob-risk-iras-final.pdf [https://perma.cc/Q8WF-XLU2].

151. GROMMON ET AL., supra note 148, at 1.

152. Id. at 13 . 
bond was set before the pretrial pilot. ${ }^{153}$ The study compared this data to the data from cases during the pretrial release where an individual was granted an order of release without monetary bail. ${ }^{154}$ The results did not match the expected release decisions. ${ }^{155}$ For example, an individual with zero previous FTAs was granted bond ${ }^{156}$ over $70 \%$ of the time before the end of monetary bail. ${ }^{157}$ But only a little over $29 \%$ of individuals with no previous FTAs were granted an order for release during the pretrial pilot. ${ }^{158}$ Since pretrial bail is intended to ensure an individual returns to trial, this study raises questions about whether the court is unnecessarily holding individuals. The results suggest that either the court is not taking the IRAS-PAT results into consideration, or the court is skeptical about ending monetary bail. ${ }^{159}$

Indiana judges and prosecutors expressed concern about the IRAS-PAT. ${ }^{160}$ Some think that relying on self-reporting is ineffective. ${ }^{161}$ For example, an individual with a substance use disorder is unlikely to admit to being an addict during the assessment. ${ }^{162}$ Judges and prosecutors also think that there are inadequate resources to sustain the IRAS-PAT. ${ }^{163}$ Nearly half of the IRAS-PAT pilot counties did not have pretrial services staff present at the initial court hearing. ${ }^{164}$ One county did not administer the IRAS-PAT until after the initial court hearing. ${ }^{165}$ Some judges and prosecutors also find the implementation timeconsuming and logistically difficult, which makes getting pretrial services officers on board challenging. ${ }^{166}$ For the IRAS-PAT to be applied consistently across the state of Indiana, these concerns must be addressed.

\section{A Danger to the Public: Risk of Bias and Technical Violations}

Pretrial reform should make "pretrial detention 'the carefully limited exception" and should only apply to "cases where no conditions of release can assure that an individual will return to court and will not pose a risk to public

153. Id. at 6 .

154. Id. at 10-12.

155. Id. at 13 .

156. "Bail is the money a defendant must pay in order to get out of jail. A bond is posted on a defendant's behalf, usually by a bail bond company, to secure his or her release." Bail and Bonds, JuSTIA, https://www.justia.com/criminal/bail-bonds/ (last visited Sept. 4, 2021) [https://perma.cc/ 2PXH-85GN].

157. GROMMON ET AL., supra note 148, at 10.

158. Id.

159. Id.

160. Id. at 6 .

161. Id.

162. Id.

163. Id.

164. See id. at 17.

165. Id.

166. Id. at 6 . 
safety." 167 However, studies have shown that risk assessment tools that weigh violence as a factor can lead to judges overestimating the risk of an individual engaging in pretrial violence. ${ }^{168}$ Overestimating violence results in judges detaining more individuals than what is often justified. ${ }^{169}$ Moreover, people with mental illness experience longer pretrial detention waiting periods than individuals who do not have mental illness. ${ }^{170}$ Detention can be detrimental for individuals with mental illness. For these individuals, even short periods of detainment can increase the chance of future involvement with the criminal justice system. ${ }^{171}$ This is because a stint in jail can "create disruptions in care, aggravate symptoms, and potentially jeopardize necessary supports, such as housing." 172 Decision-makers should not heavily weigh these factors in the risk assessment when mental illness is suspected or identified.

Rule 26 also allows authorities to detain individuals who may not be a threat to the public safety. Under Rule 26, an arrestee cannot be released if he or she is "on pretrial release not related to the incident that is the basis for the present arrest" or "on probation, parole, or other community supervision." ${ }^{.173}$ Neither one of these exceptions suggests that an individual is a danger to the public. For instance, parole violations can result in jail, but these violations could be for failing a drug test or failing to show up at a probation office. ${ }^{174}$ Technical violations should not result in an individual being sent to jail. These violations may occur because of a substance use disorder, which usually involves a recovery process and often includes relapsing. ${ }^{175}$ In these instances, a return to jail is unnecessary to protect public safety. In reality, it is a severe and mostly ineffective way to handle the parole violation. ${ }^{176}$

167. Hallie Fader-Towe \& Fred C. Osher, Improving Responses to People with Mental Illnesses at the Pretrial Stage, Council ST. Gov'Ts Just. CTR. 7 (2015), https://csgjusticecenter. org/wp-content/uploads/2020/02/Improving_Responses_to_People_with_Mental_Illnesses_at_ the_Pretrial_Stage_Essential_Elements.pdf [https://perma.cc/N2YX-3BYK] (internal citation omitted).

168. Martha Minow et al., Technical Flaws of Pretrial Risk Assessments Raise Grave Concerns, BERKMAN KLEIN CTR. FOR INTERNET \& SOC'Y HARV. U. 2 (July 17, 2019), https://damprod.media.mit.edu/x/2019/07/16/TechnicalFlawsOfPretrial_ML\%20site.pdf?source=post_page [https://perma.cc/VCY3-DEZH].

169. Id.

170. Fader-Towe \& Osher, supra note 167, at 7.

171. Id.

172. Id. at 25-26.

173. Ind. CODE ANN. § 35-33-8-3.8(b) (West 2020).

174. Peggy McGarry et al., Vera Inst. of Justice, The Potential of Community Corrections to Improve SAfety and Reduce Incarceration 12 (2013), https:/www. vera.org/downloads/Publications/the-potential-of-community-corrections-to-improve-safety-andreduce-incarceration-configure/legacy_downloads/potential-of-community-corrections.pdf [https://perma.cc/G72W-FCAA].

175. Id. at 14 .

176. See generally To Safely Cut Incarceration, States Rethink Responses to Supervision 


\section{WHAT SHOULD WE DO?}

\section{A. Reform Must Consider Individuals with Mental Illness and Substance Use Disorder}

Individuals with mental illness and substance use disorder make up a substantial percentage of the incarcerated population, but Indiana's criminal reform has failed to address this population. Instead, Indiana created a perception of reform that has left more problems than solutions. The Indiana legislature is working to find solutions to address the issues created by their legislation. This legislation will result in more spending without the necessary solutions to reduce incarceration. For criminal justice reform in Indiana to successfully address individuals with mental illness and substance use disorder, Indiana must implement reform that focuses specifically on the needs of this population. Indiana must offer more effective pre-arrest diversion strategies, pretrial reform that encompasses the needs of those with mental illness and substance use disorder, public defenders who are willing to be zealous advocates, and more expansive treatment facilities for mental health and addiction.

\section{B. Pre-Arrest Diversion}

Pre-arrest diversion is one of the most effective strategies to reduce jail overcrowding and recidivism. Since even short periods of time in jail can create disruptions in care, pre-arrest diversion helps ensure that individuals in need of services receive assistance without the risks caused by disruption from incarceration. ${ }^{177}$ In Florida, Miami-Dade County has implemented pre-arrest diversion programs that Indiana can look to as models for pre-arrest diversion success. The Criminal Mental Health Project, established in 2000, was created by Miami-Dade County to divert nonviolent misdemeanants and lower-level felons with serious mental illnesses and substance use disorders to community-based treatment and support services. ${ }^{178}$ The program has both a pre-booking diversion program that includes Crisis Intervention Team (CIT) training for law enforcement officers and a post-booking service for individuals in jail awaiting adjudication. ${ }^{179}$

The CIT training consists of officers who receive forty hours of training in psychiatric diagnoses, suicide intervention, substance abuse issues, behavioral deescalation techniques, mental health and substance abuse laws, and local

Violations, Pew Charitable Tr. (July 16, 2019), https://www.pewtrusts.org/en/research-andanalysis/issue-briefs/2019/07/to-safely-cut-incarceration-states-rethink-responses-to-supervisionviolations [https://perma.cc/L7TM-JELG].

177. Fader-Towe \& Osher, supra note 167, at 25-26.

178. Criminal Mental Health Project, Eleventh Jud. CIR. Fla., https://www.jud11.flcourts. org/Criminal-Mental-Health-Project (last visited Sept. 4, 2021) [https://perma.cc/AK67-DUR6].

179. Id. 
resources for those in crisis. ${ }^{180}$ The intent is for officers to be able to recognize the signs and symptoms of mental illness and substance use disorders so that the officers can respond more effectively to individuals in crisis. ${ }^{181}$ As a result, the individual can be diverted to services, rather than to jail. ${ }^{182}$

CIT training gives police officers more tools to do their job effectively and to ensure that individuals in need of services are not being sent to the criminal justice system, which cannot adequately support their needs. ${ }^{183}$ Some communities have found that CIT training has reduced the time officers spend responding to individual mental health calls because the officer is trained to quickly identify the issue and provide a solution. ${ }^{184}$ The ability to respond to such calls quickly puts officers back into the community to handle threats to public safety ${ }^{185}$ CIT training also produces cost savings because "incarceration is costly compared to community-based treatment. For example in Detroit an inmate with mental illness in jail costs $\$ 31,000$ a year, while community-based mental health treatment costs only $\$ 10,000$ a year." 186

Not everyone experiencing mental illness needs to be hospitalized: "The Psychiatric Emergency Response Team (PERT) model has been operating in San Diego, CA . . . since 1996. PERT teams consist of police officers with training in mental illness and mental health professionals, who both respond to calls involving PMI. Police officers receive eighty hours of initial training," 187 which provides techniques to respond safely and effectively in crisis situations. ${ }^{188}$ The training teaches officers who did not know how to effectively deal with individuals in distress how to provide compassionate care, rather than respond in ways that may make the situation even worse. ${ }^{189}$ It is estimated that PERT has allowed law enforcement officers to divert $50 \%$ of calls involving individuals with mental illness, not only from jail, but also hospitals. ${ }^{190}$ Implementing a

180. Id.

181. Pre-Booking Diversion, Eleventh Jud. Cir. Fla., https://www.jud11.flcourts.org/PreBooking-Diversion (last visited Sept. 4, 2021) [https://perma.cc/5EH5-BH4G].

182. Id.

183. Crisis Intervention Team (CIT) Programs, Nat'L Alliance on Mental Illness, https://www.nami.org/get-involved/law-enforcement-and-mental-health (last visited Sept. 4, 2021) [https://perma.cc/2QAD-UYV4].

184. Id.

185. Id.

186. Id.

187. Kathleen Hartford et al., Pre-Arrest Diversion of People with Mental Illness: Literature Review and International Survey, 24 BeHAV. SCI. \& L. 845, 850 (2006). PMI refers to "persons with mental illness." Id. at 845 .

188. Improved Responses in Psychiatric Crises: The Psychiatric Emergency Response Team Program, SAn Diego CounTy GRAND JuRY 1 (May 30, 2018), https://www.sandiegocounty.gov/ content/dam/sdc/grandjury/reports/2017-2018/IMPROVEDRESPONSESINPSYCHIATRIC CRISESReport1.pdf [https://perma.cc/6XL6-BCUE].

189. Id.

190. Id. 
program such as PERT in Indiana could help reduce the number of resources spent on individuals with mental illness who simply need help deescalating.

"The Mobile Crisis Team (MCT) model has been operating in Santa Fe, New Mexico .... It is comprised of behavioral health experts who help police officers at the scene decide a course of action in incidents involving mentally ill [individuals]." ${ }^{\prime 191}$ When an officer responds to a person experiencing a behavioral health crisis, the MCT meets the officer at the scene. ${ }^{192}$ The goals of the program are to lessen reliance on hospital emergency rooms and identify the underlying issues that caused the mental health crisis. ${ }^{193}$ If necessary, "[c]ase managers may [also] refer the person to an appropriate outpatient facility." 194

Since Recovery Works only connects individuals charged with a felony to community-based providers, ${ }^{195}$ pre-arrest diversion efforts such as the examples listed above would ensure that Indiana also addresses the population of individuals with mental illness and substance use disorder who are not charged with crimes or are only charged with misdemeanors. All of the diversion programs listed require additional officer training, but the training pays for itself when there is a decrease in inmate population. ${ }^{196}$ Pre-arrest diversion programs can also reduce the necessary spending on programs like Recovery Works because fewer individuals in need of services will be sent to jail. Ultimately, it is important to keep individuals who do not need to be in jail out of jail. ${ }^{197}$ Being incarcerated for even a short period of time can have lasting effects on those with mental illness and substance use disorder. ${ }^{198}$ In Marion County, "one third of those who die from an accidental overdose ... were in the county jail in the year prior to death, and most of them died within a week of release." 199 This statistic illustrates just how critical it is to ensure individuals are receiving treatment rather than being incarcerated. Pre-arrest diversion is the most effective practice for ensuring individuals in need of services are supported.

191. Hartford et al., supra note 187 , at 850 .

192. Anne Constable, Presbyterian Launches Response Team to Aid in Mental Health Crises, SANTA Fe New MeXiCAN (July 8, 2015), https://www.santafenewmexican.com/news/health_and science/presbyterian-launches-response-team-to-aid-in-mental-health-crises/article_8df2c979-9a5d5898-8b50-02d6d437a5cb.html [https://perma.cc/BP9E-TFLU].

193. Id.

194. Hartford et al., supra note 187 , at 850 .

195. 2019 Annual Evaluation, supra note 24, at 83.

196. See Improved Responses in Psychiatric Crises, supra note 188.

197. See Rethinking Jails, Reframing Public Defense: Making the Case for the System-Wide Benefits of Effective Defenders, NAT'L LEGAL AID \& DEFENDER Ass'N (2016), http://www.nlada. org/sites/default/files/NLADA-SJC-reframing-public-defense-toolkit.pdf [https://perma.cc/46EMFLGW].

198. See id.

199. Nov. 6 Meeting, supra note 143, at 13:18. 


\section{Pretrial Reform for Individuals with Mental Illness}

With the adoption of Rule 26, individuals with mental illness should be identified early in the incarceration process. When these individuals are identified through the IRAS-PAT, it is critical that the court understand that individuals who are categorized as low-risk, regardless of their mental illness, are not denied pretrial release. ${ }^{200}$ It is also imperative that pretrial screenings are conducted as close to booking as possible so that jail staff are aware of the inmate's needs, such as required medication. ${ }^{201}$ In the event an individual with mental illness is not identified during prescreening, it is important that jails have specialized units where pretrial staff are trained on the signs and symptoms of mental health. ${ }^{202}$ Additionally, smaller caseloads for officers working with arrestees with behavioral needs will allow officers to dedicate more time and attention to those individuals. ${ }^{203}$ This attention will allow for a better assessment of the individual's needs, which will ensure the individual gets appropriate treatment and the individual's mental illness is not exacerbated. ${ }^{204}$

Pretrial screenings can also be utilized to provide necessary information to make decisions about the conditions of an individual's release. ${ }^{205}$ For example, if the individual is assigned to a community-based provider as a condition of release, some individuals may also already have relationships with communitybased providers. ${ }^{206}$ Rather than giving the individual a new community-based provider, he or she should be assigned to the one that already knows the individual's history and specific needs. ${ }^{207}$ Regardless of whether an individual has an existing community-based provider or is assigned one, it is important that the jail establish a relationship with that provider so that each agency knows important medical or psychosocial information such as prescriptions that the defendant needs to take. ${ }^{208}$

During pretrial release, individuals with mental illness and substance use disorder should be given pretrial supervision plans that meet their individual needs. ${ }^{209}$ While some individuals with mental illness may be able to succeed without any modifications to their pretrial supervision, others may need specific strategies that will benefit their success on pretrial release. ${ }^{210}$ Since mental illness can impact organization, it is common for individuals with mental illness to need

\footnotetext{
200. Fader-Towe \& Osher, supra note 167, at 7.

201. Id. at 30 .

202. Id. at 35 .

203. Id.

204. $I d$.

205. Id. at 33 .

206. Id.

207. Id.

208. Id at 35 .

209. Id.

210. Id. at 36 .
} 
reminders for things such as when they need to return to court. ${ }^{211}$ Also, regular conversations between the community-based provider and the officer can help the officer understand why an individual is not meeting conditions of release. ${ }^{212}$ Returning to jail interrupts an individual's treatment and "should be reserved as a last resort for people who truly cannot be safely managed in the community." 213

\section{Holistic Public Defender Services}

The U.S. and Indiana Constitutions require that "every person accused of a crime [has] the right to be represented by an attorney when they cannot afford to hire one." ${ }^{214}$ The right to counsel extends beyond criminal prosecutions. ${ }^{215}$ Individuals also have the right to counsel when facing mental health commitments. ${ }^{216}$ In most states, public defenders are hired by the state and managed by a centralized state office, but in Indiana, public defense is largely county-funded. ${ }^{217}$ For example, judges in counties with a population of fewer than 400,000 people are allowed to contract with an attorney or group of attorneys to provide public defense services ${ }^{218}$; yet the very first principle of the American Bar Association's "Ten Principles of a Public Defense Delivery System" indicates public defense "should be independent from political influence and subject to judicial supervision only in the same manner and to the same extent as retained counsel." 219 While local judges may be acting in good faith when they directly hire counsel, the judges are ultimately in control of local public defense services. ${ }^{220}$ This control can impact the level of advocacy a public defender in Indiana provides, which can result in individuals with mental illness and substance use disorder being cycled through the criminal justice system rather than getting the appropriate treatment they need. ${ }^{221}$

"According to a survey conducted by the [Indiana Task Force on Public

211. $I d$.

212. Id.

213. Id.

214. Ind. TAsk Force ON Pub. Def., Executive Summary: Findings And Recommendations of the Reporting Subcommittee to the Indiana Public Defender COMMISSION 9 (2018), https://www.in.gov/publicdefender/files/Pages-from-Task-Force-Report-v1exec-summary.pdf [https://perma.cc/J563-F8YW] [hereinafter IND. TASK FORCE ON PUB. DeF., EXECUTIVE SUMMARY].

215. Id.

216. $I d$.

217. $I d$.

218. Standards for Indigent Defense Services in Non-capital Cases, IND. Pub. Defender COMMission (June 8, 2016), https://www.in.gov/publicdefender/files/indigent-defense-non-cap.pdf [https://perma.cc/736E-UGLE].

219. Ten Principles of a Public Defense Delivery System princ. 1 cmt. (Am. Bar Ass'n 2002) (citations omitted)

220. Ind. TASk Force on Pub. Def., Executive Summary, supra note 214, at 10.

221. Id. at 11 . 
Defense], $76.34 \%$ of respondents agree there is pressure on courts to move through cases quickly due to time constraints." ${ }^{222}$ In fact, many counties in Indiana fail to provide arrestees with public defenders at initial hearings. ${ }^{223}$ Part of the reason for the lack of representation at the initial hearing is because Indiana has no presumptive indigence determination. ${ }^{224}$ Some states presume that a defendant is "eligible for appointed counsel if the defendant is a current recipient of a state or federally administered public assistance program," such as "Food Stamps, Medicaid, [or] Supplemental Security Income (SSI)."225

For Rule 26 to be effective, a public defender needs to be present during the IRAS-PAT to advocate for the defendant's release. During the Rule 26 pilot phase, courts ensured that public defenders were available at the initial hearings to aid in the release decisions. ${ }^{226}$ It is critical for the public defender to advocate for a low-risk arrestee with a mental illness or substance use disorder who may be perceived as dangerous because of that mental illness or substance use disorder. ${ }^{227}$ The presence of a public defender can also help ensure that low-risk clients are scored correctly and that their mental illness is not given unnecessary weight in their assessment. ${ }^{228}$ Not only do public defenders prevent low-risk clients from being subject to unnecessary incarceration, but they also increase the individual's willingness to comply with court orders when on pretrial release. ${ }^{229}$ This compliance allows those with mental illness and substance use disorders to get the treatment they need and to avoid any additional issues with the court.

Indiana public defenders currently complain of more cases than they can handle, which means additional funding may be required to hire more public defenders. ${ }^{230}$ While upfront costs are required to provide a more effective public defender service, the reduction in wasteful spending on jails will make up for it. ${ }^{231}$ When a public defender advocates for clients, individuals with mental illness and substance use disorder are safely released, reducing the number of people in jail and allowing public funds to be spent more strategically. Even without additional funding, counties can ensure public defenders are at the initial hearing by being

222. $I d$.

223. Id. at 12 .

224. Id. at 14 .

225. See Court-Appointed Counsel Procedures \& Guidelines Manual, DeP'T Jud. Servs. at 2-4, http://www.courts.state.va.us/courtadmin/aoc/djs/resources/manuals/ctapptatty/chapter02.pdf (last visited Sept. 5, 2021) [https://perma.cc/BJ74-64S3].

226. GROMmON ET AL., supra note 148, at 17.

227. See Rethinking Jails, supra note 197.

228. Id.

229. Id.

230. Angela Brauer, Public Defenders in Indiana Say They Are Bogged Down with Misdemeanor Cases, CBS4 (Feb. 11, 2019, 8:21 AM), https://cbs4indy.com/2019/02/11/publicdefenders-in-indiana-say-they-are-bogged-down-with-misdemeanor-cases/ [https://perma.cc/Q2F7USWA].

231. See id. 
resourceful in how they assign attorneys to cases. ${ }^{232}$ For example, a county could have public defenders who focus only on pretrial advocacy or pool resources with neighboring jurisdictions to ensure availability of counsel. ${ }^{233}$

\section{E. Graduated Responses and Incentives}

Rather than detaining individuals in jail who have violated the conditions of their parole, but are not a danger to the public, the Indiana Supreme Court should revise Rule 26 to include individuals who are arrested while on probation and parole. Instead of excluding these individuals from pretrial release, Indiana should impose a graduated response system. This system would require probation officers to respond to parole infractions appropriately and proportionately. ${ }^{234}$ Behaviors such as missed appointments or failed drug tests can be met with "sanctions that are proportional to the violation." ${ }^{335}$ Also, an officer who responds to every parole violation may discover that the individual is going through a difficult period or needs different parole conditions. ${ }^{236}$ For individuals who are struggling to follow the conditions of their parole, rather than sending them to jail, officers can send them to day treatment centers that offer rehabilitative programming such as substance abuse treatment. ${ }^{237}$ Research has proven that day centers reduce recidivism, which makes them an even more appealing option than jail. . $^{238}$

Research also shows that a ratio of at least four positive verbal responses to each negative verbal response is the most effective for behavior change. ${ }^{239}$ This means that probation officers can directly influence an individual's chance of success by using positive reinforcement. ${ }^{240}$ Rather than resorting to jail as the punishment for parole violations, Indiana should encourage counties to use parole violations as a way to gain information about the individual.

\section{CONCLUSION}

Criminal justice reform requires looking at the root cause of mass incarceration and implementing strategies that keep individuals out of jail. Individuals with mental illness and substance use disorder are overrepresented in

232. See Kathleen Casey et al., Ind. Task Force on Pub. Def., Findings and

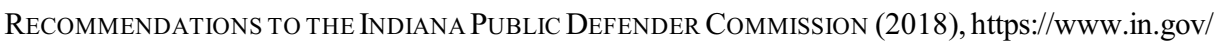
publicdefender/files/Indiana-Task-Force-Report.pdf [https://perma.cc/K2E5-LQMH].

233. Lisa Pilnik, NAT'L Inst. of CoRR., U.S. DeP'T of Justice, NIC ACCESSION No. 032831 , AFramework for Pretrial Justice: Essential Elements of an EfFective Pretrial System AND AGENCY (2017).

234. MCGARRY ET AL., supra note 174 , at 18.

235. Id. (citation omitted).

236. Id.

237. Id. at 21 .

238. $I d$.

239. Id. at 19 .

240. Id. 
jails because of an overreliance on jail to deal with these individuals. ${ }^{241}$ Representative Steuerwald said he wanted to create criminal justice reform that treated individuals who we are "afraid of" (people with mental illness and substance use disorder) differently from the people we are "mad at" (people who have committed violent crimes); yet statistically, both groups of people end up incarcerated. ${ }^{242}$

If Indiana wants true criminal reform, Indiana must begin implementing strategies that keep people out of jail. HEA 1006 has ultimately created county jail overcrowding, which exacerbates symptoms for individuals with mental illness. ${ }^{243}$ Individuals with substance use disorder are cycling through jail and community correction efforts like Recovery Works because of the eligibility requirements and lack of sufficient funding. Rule 26 is a good start, but many individuals with mental illness and substance use disorder should not be arrested to begin with. Pretrial diversion programs will help reduce the number of individuals incarcerated and minimize the chances of individuals with mental illness cycling through county jails. ${ }^{244}$ For individuals with mental illness and substance use disorder who end up getting arrested, public defenders who are zealous advocates will ensure that these individuals do not stay in jail because of their illness. ${ }^{245}$ Real criminal justice reform does not preserve the status quo.

241. MCGARRY ET AL., supra note 174, at 2.

242. Sept. 30 Meeting, supra note 1, at 15:00.

243. 2019 Annual Evaluation, supra note 24, at 85.

244. Rethinking Jails, supra note 197, at 8.

245. Id. 